\title{
The influence of physical activity and eating behaviour on body mass index in children and adolescents: A review the literature
}

\section{Influencia de la práctica de la actividad física y del comportamiento dietético en el índice de masa corporal de niños y adolescentes: Revisión de literatura}

\begin{abstract}
The object of the present study was to carry out a literature review to analyze the influence of physical activity and dietary behavior on body mass index in school-age children and adolescents. A search was carried out using the PubMed and LILACS databases, in which 1,412 articles were found. After application of inclusion and exclusion criteria, $17 \mathrm{stu}$ dies were selected for qualitative analysis. Overweight and obesity were related with incorrect dietary habits (skipping breakfast, consumption of foods with high fat contents and high-sugar soft drinks), low levels of physical activity and long hours devoted to sedentary activities (playing video games or watching TV) were also related.
\end{abstract}

Keywords: Adolescents, Body mass index, Children, Dietary behaviour, Physical activity.

\section{RESUMEN}

El objetivo de este estudio fue analizar, mediante una revisión de la literatura, la influencia de la práctica de actividad física y del comportamiento dietético sobre el índice de masa corporal de niños y adolescentes en fase escolar. Se realizó una búsqueda en las bases PubMed y LILACS. Se encontraron 1.412 artículos. Tras la aplicación de los criterios de inclusión y exclusión fueron seleccionados 17 estudios para realizar un análisis cualitativo. El sobrepeso y la obesidad están relacionadas a una alimentación inadecuada (saltar el desayuno, consumo de alimentos con alto contenido de grasa y de bebidas azucaradas), niveles bajos de actividad física y longas horas realizando actividad sedentaria (jugando video-juegos o visualizando la TV). Palabras clave: Actividad física, Adolescentes, Comportamiento dietético, Índice de masa corporal, Niños.

\section{INTRODUCTION}

The incidence of overweight and/or obesity in children and adolescents has increased significantly, principally in developed countries and certain segments of developing countries'. In Latin America, it is estimated that between 42,4 and 51,8 million children and adolescents suffer from excess body mass, representing $20-25 \%$ of this population ${ }^{2}$. In European countries, the prevalence of infant and juvenile
Francisco Macedo Uchôa ${ }^{1}$, Romário Pinheiro Lustosa², Joaquim Cintra Andrade ${ }^{3}$, Welton Nogueira Godinho ${ }^{4}$, Ágata Marques Aranha ${ }^{5}$, Naira F. Deana ${ }^{6}$, Nilton Alves ${ }^{7,8}$.

1.Doctorate student in Sport Sciences - University of Trás-os-Montes and Alto Douro, Vila Real, Portugal. 2. State University of Ceará, Fortaleza, Brazil.

3. Federal University of Santa Catarina, Florianópolis, Brazil. 4. Higher Institute of Biomedical Sciences, State University of Ceará, Fortaleza, Brazil.

5. Departament of Desporto, University of Trás-os-Montes and Alto Douro, Vila Real, Portugal.

6.Center for Research in Epidemiology, Economics and Oral Public Health(CIEESPO), Faculty of Dentistry, Universidad de La Frontera, Temuco, Chile.

7.Center of Research in Applied Morphology. Faculty of

Dentistry Universidad de La Frontera, Temuco, Chile. 8. Center of Excellence in Surgical and Morphological Research (CEMyQ), Faculty of Medicine, Universidad de La Frontera, Temuco, Chile.

Corresponding author: Nilton Alves Av. Center of Research in Applied Morphology. Faculty of Dentistry Francisco Salazar, 1145, Casilla 54-D, Temuco, Chile. E-mail: nilton.alves@ufrontera.cl

Este trabajo fue recibido el 26 de marzo de 2018. Aceptado con modificaciones: 22 de octubre de 2018. Aceptado para ser publicado: 28 de diciembre de 2018.

obesity is over $20 \%^{3}$, while the figure is lower in Asian countries, estimated to be between $5 \%$ and $10 \%{ }^{4}$. Obesity not only leads to an increase in the incidence of diseases, such as diabetes, hypertension, cerebrovascular accidents and cancer, but it can also cause psychological problems, such as a reduction in self-esteem and increasing depression in children and adolescents subject to strong socio-cultural pressure to possess a thin body ${ }^{5}$. Overweight children and adolescents are more likely to follow unhealthy diets to try to control their weight compared to those whose weight is normal6; in particular, overweight girls present a higher risk of developing eating disorders due to the socio-cultural pressure to be thin ${ }^{7}$.

Dietary behaviour is determined by demographic, 
nutritional and behavioural factors ${ }^{8}$. During their school years, young people are more prone to oscillating feelings and behaviours related with their bodies, for example in dietary habits and physical activity ${ }^{9,10}$. As a result of these factors, studies have reported a high prevalence of healthdamaging dietary behaviour among school-age adolescentes ${ }^{9,11}$ principally girls ${ }^{12}$. Many characteristics of the environment may help to determine a child's physical activity (PA), including the parents' attitude and the stimulus they provide to take part in sports, the percentage of time spent outdoors, the geographical location and the time of year ${ }^{13,14}$. Sedentarism, economic and socio-cultural influences and excessive passive eating are obesogenic factors which lead to an increase in the prevalence of child obesity ${ }^{15}$. Kruger et al. ${ }^{14}$ indicate the importance of applying assessment strategies in order to identify children who are prone to overweight/ obesity, since treating adults for obesity does not generally produce good results. Many studies have used instruments to measure specific behaviours, knowledge, attitudes and intentions in dietary behaviour and the practice of PA in adolescents and children, and their influence on body mass index (BMI) in this population. The aim of the present study was to carry out a literature review to analyze the influence of physical activity and dietary behavior on BMI in schoolage children and adolescents.

\section{MATERIAL AND METHOD}

This study is characterised as a literature review involving a critical analysis of published literature on physical activity and dietary behaviour in schoolchildren.

A search was carried out of the PubMed and LILACS electronic databases. The key words used in Portuguese and English were: 'physical activity OR physical exercise' AND 'teenagers or schoolchildren' AND 'overweight' AND 'obesity' AND 'dietary behaviors OR food behavior'. The bibliographic search was limited by date (2000-2017) and language (Portuguese, Spanish, and English).

The inclusion criteria were for original studies, in human beings, descriptive and analytical, which used instruments to analyse the impact of practising PA and dietary behaviour on the BMI of schoolchildren. The exclusion criteria excluded studies related with the topic outside the school environment, studies which analysed specific sports, studies carried out in periods outside the classroom routine, literature reviews, points of view/opinions of specialists, validation studies, monographs, dissertations and theses.

After the results had been obtained, duplicate articles were excluded and a preliminary selection was made by reading the titles and abstracts of the manuscripts. Titles and abstracts were selected independently by two investigators (F.N.M.U. and R.P.L.) to verify their eligibility. In cases of discrepancy, consensus was obtained by discussion or by consulting a third reviewer (N.A.). The references that appeared to fulfil the inclusion criteria were reviewed in full text by the same reviewers (F.N.M.U. and R.P.L.). The full texts of potentially eligible articles were then analysed.
The data in each article selected were analysed to obtain the study design, total sample size, sex, age and origin of the individuals in the sample, instruments used and principal results.

\section{RESULTS}

We identified 1,412 publications with the key word combinations in all the databases selected, with 40 duplicated articles. After reading the title and abstract, studies which did not meet the inclusion criteria were excluded. The full texts of the remaining articles were read, and 17 were selected for qualitative analysis (Figure 1). The characteristics of the studies selected are provided in table 1.

The total number of children and adolescents was 60,250 , of both sexes, between 6 and 19 years of age, including whites, blacks, Hispanics, Mexicans, Asians, American Indians, Latin Americans, Greeks, Europeans and South Africans. Between $55.5 \% 16$ and $92.1 \%{ }^{14}$ of the children and adolescents presented normal weight. The proportion of underweight children was between $2 \%{ }^{17}$ and $4.7 \%{ }^{18}$. The proportion of overweight children varied between $10.8 \%{ }^{19}$ and $30.9 \%{ }^{20}$, and the proportion of obese children between $3.9 \%{ }^{19}$ and $24.3 \%{ }^{16}$.

Three studies reported an association between sedentary behaviour and incorrect dietary behaviour. A relationship between sedentarism and overweight was observed in 9 studies (56.3\%), and an association between incorrect dietary behaviour and overweight was observed in 5 studies (31.25\%).

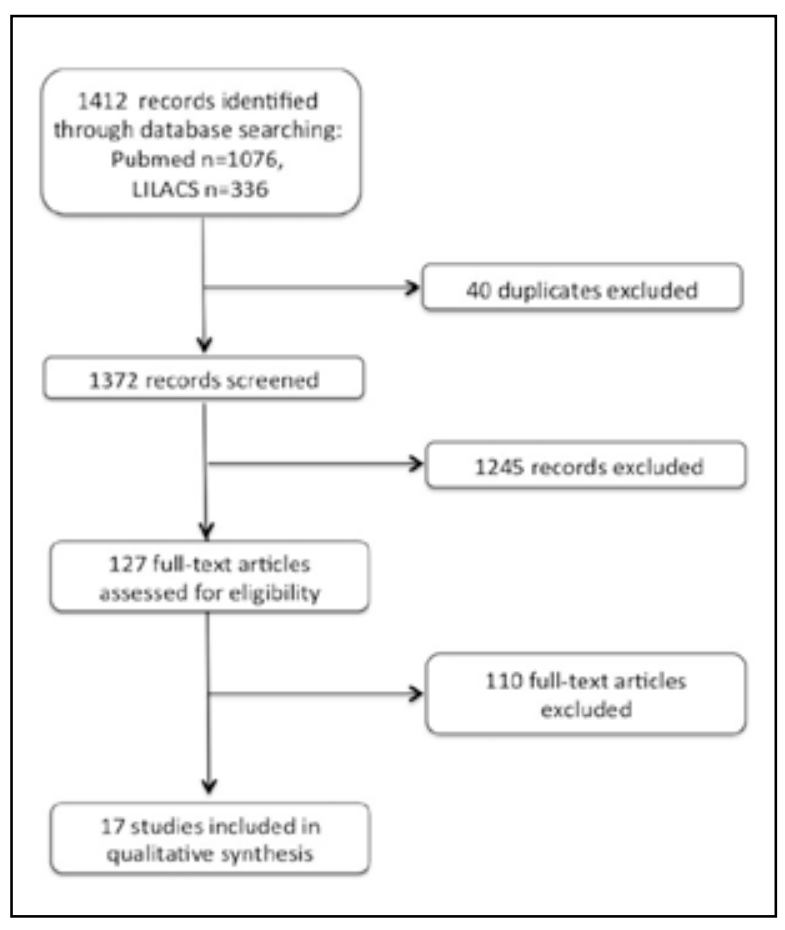

Figure 1. Study selection process flowchart. 
Table 1. Characteristics of the studies included. $\mathrm{NI}=$ no information, $\mathrm{F}=$ females, $\mathrm{M}=$ males, $\mathrm{PA}=$ Physical Activity.

\begin{tabular}{|c|c|c|c|c|c|c|c|}
\hline Author & Design & Total $\mathbf{n}$ & Sex & Population & $\begin{array}{c}\text { Percentage of } \\
\text { subjects by BMI }\end{array}$ & Instruments & Primary results \\
\hline $\begin{array}{l}\text { Farajian } \\
\text { et al. }{ }^{30}\end{array}$ & $\begin{array}{l}\text { Cross- } \\
\text { sectional }\end{array}$ & 4786 & $\begin{array}{l}\text { F: } 50.7 \% \\
\text { M: } 49.3 \%\end{array}$ & $\begin{array}{l}\text { Greek pupils } \\
\text { aged } 10 \\
\text { to } 12 \text { years. }\end{array}$ & $\begin{array}{l}\text { Underweight } \\
4.2 \% \text { (girls:5.0\%; } \\
\text { boys: } 3.3 \% \text { ) } \\
\text { Overweight } 29.5 \% \\
\text { (girls: } 29.2 \% \text {; } \\
\text { boys: } 20.9 \% \text { ) } \\
\text { Obese } 11.7 \% \\
\text { (girls: } 10.6 \% \text {; } \\
\text { boys: } 12.9 \% \text { ) }\end{array}$ & $\begin{array}{l}\text { 1. Food Frequency } \\
\text { Questionnaire (FFQ) } \\
\text { 2.Mediterranean } \\
\text { Diet Quality Index } \\
\text { for children and } \\
\text { adolescents (KIDMED) } \\
\text { 3. Physical activity } \\
\text { Questionnaire for } \\
\text { Older Children (PAQ-C) }\end{array}$ & $\begin{array}{l}\text { Children with healthier } \\
\text { eating habits, based on a } \\
\text { Mediterranean diet, are } \\
\text { more physically active }\end{array}$ \\
\hline $\begin{array}{l}\text { lannotti } \\
\text { and } \\
\text { Wang }^{25}\end{array}$ & $\begin{array}{l}\text { Cross- } \\
\text { sectional }\end{array}$ & $\begin{array}{l}2001- \\
2002 \\
14,607 \\
2005- \\
2006 \\
9,150 \\
2009- \\
2010 \\
10,848\end{array}$ & $\begin{array}{c}2001- \\
2002 \\
F: 7630 \\
M: 6977 \\
\\
2005- \\
2006 \\
F: 4719 \\
M: 4431 \\
2009- \\
2010 \\
F: 5261 \\
M: 5587\end{array}$ & $\begin{array}{l}\text { US adolescents } \\
\text { aged } 11 \text { to } 16\end{array}$ & $\begin{array}{l}\text { Underweight } \\
4.7 \% / 3.7 \% / 4.2 \% \\
\text { Normal weight } \\
70.1 \% / 66.6 \% / \\
66.5 \% \\
\text { Overweight } \\
14.9 \% / 17.0 \% / \\
16.6 \% \\
\text { Obese } \\
10.3 \% / 12.7 \% \text { / } \\
12.7 \%\end{array}$ & $\begin{array}{l}\text { 1. Socio-demographic } \\
\text { Variables } \\
\text { 2. Physical activity } \\
\text { 3. Sedentary } \\
\text { behaviour time } \\
\text { 4. Health Behaviour } \\
\text { in School-Aged } \\
\text { Children } \\
\text { 5. Food-frequency } \\
\text { questionnaire. }\end{array}$ & $\begin{array}{l}\text { Adolescents present a } \\
\text { high frequency of } \\
\text { obesogenic habits; } \\
\text { the majority do not } \\
\text { carry out the recommended } \\
\text { minimum of } 60 \text { minutes } \\
\text { PA per day and do not } \\
\text { consume more than } 5 \\
\text { portions of fruit and } \\
\text { vegetables per day. }\end{array}$ \\
\hline $\begin{array}{l}\text { Kruger } \\
\text { et al. }{ }^{14}\end{array}$ & $\begin{array}{l}\text { Cross- } \\
\text { sectional }\end{array}$ & 1257 & $\begin{array}{l}\text { F:649 } \\
\text { M: } 608\end{array}$ & $\begin{array}{l}\text { 10- to } 15 \text {-year old } \\
\text { school children in } \\
\text { the North West } \\
\text { Province of South } \\
\text { Africa. }\end{array}$ & $\begin{array}{l}\text { Normal weight } \\
92.1 \% \\
\text { Overweight/obese } \\
7.8 \%\end{array}$ & $\begin{array}{l}\text { 1. Demographic, } \\
\text { socio-economic, } \\
\text { environmental and } \\
\text { health factors } \\
\text { 2. Multiple-pass } \\
\text { 24-hour recall } \\
\text { 3. Physical activities } \\
\text { over the previous } 24 \mathrm{~h}\end{array}$ & $\begin{array}{l}\text { - The frequency of over- } \\
\text { weight/obese chidren } \\
\text { was lower in children } \\
\text { aged } 11 \text { years }(6.7 \%) \\
\text { and higher in } \\
\text { children aged } 10 \text { years } \\
(9.1 \%) \text { and } 15 \text { years } \\
(9.1 \%) \text {. The greatest } \\
\text { prevalence of overweight/ } \\
\text { obesity was found in } \\
\text { female, white-skinned } \\
\text { children. } \\
\text { - Smaller households, } \\
\text { sedentarism and increasing } \\
\text { age in girls were determiner } \\
\text { of increased weight. } \\
\text { - Prevention programmes } \\
\text { should focus on increasing } \\
\text { the practice of physical } \\
\text { activity by children to } \\
\text { improve their current and } \\
\text { future weight. }\end{array}$ \\
\hline $\begin{array}{l}\text { Liberona } \\
\text { et al. }{ }^{.7}\end{array}$ & $\begin{array}{l}\text { Cross- } \\
\text { sectional }\end{array}$ & 1732 & $\begin{array}{l}\text { F: } 838 \\
\text { M: } 894\end{array}$ & $\begin{array}{l}\text { 9- to } 12 \text {-year olds } \\
\text { in primary schools } \\
\text { in the Metropolitan } \\
\text { Region of Santiago, } \\
\text { Chile. }\end{array}$ & $\begin{array}{l}\text { Normal weight } \\
59 \% \\
\text { Overweight } 22 \% \\
\text { Obese } 17 \% \\
\text { Underweight } 2 \%\end{array}$ & $\begin{array}{l}\text { 1. Food frequency } \\
\text { questionnaire, 24- } \\
\text { hour dietary recall } \\
\text { 2. HAF. Physical } \\
\text { activity questionnaire } \\
\text { 3. ESOMAR } \\
\text { questionnaire }\end{array}$ & $\begin{array}{l}\text { The high indices of } \\
\text { overweight and obesity } \\
\text { in Chilean schoolchildren } \\
\text { are due to the combination } \\
\text { of low PA and poor diet. } \\
\text { Obesity was most prevalent } \\
\text { in children from the lowest } \\
\text { socio-economic level, } \\
\text { probably due to higher } \\
\text { consumptionofcarbohydrate- } \\
\text { rich foods. }\end{array}$ \\
\hline $\begin{array}{l}\text { Manios } \\
\text { et al. } .^{20}\end{array}$ & $\begin{array}{c}\text { Cross- } \\
\text { sectional }\end{array}$ & 2492 & $\begin{array}{l}F: 1251 \\
\text { M: } 1241\end{array}$ & $\begin{array}{l}\text { Schoolchildren } \\
\text { aged 9-13 years } \\
\text { from Attica, }\end{array}$ & $\begin{array}{l}\text { Normal weight } \\
57.6 \% \\
\text { Overweight } 30.9 \%\end{array}$ & $\begin{array}{l}\text { 1. Physical } \\
\text { examination and } \\
\text { anthropometry }\end{array}$ & $\begin{array}{l}\text { Obesity was the only } \\
\text { factor which significantly } \\
\text { increased the probability }\end{array}$ \\
\hline
\end{tabular}




\begin{tabular}{|c|c|c|c|c|c|c|c|}
\hline Author & Design & Total $\mathbf{n}$ & Sex & $\begin{array}{l}\text { Aitoloakarnania, } \\
\text { Population }\end{array}$ & $\begin{array}{l}\text { Obese } 11.4 \% \\
\text { Percentage of } \\
\text { subjects by BMI }\end{array}$ & $\begin{array}{l}\text { 2. Haematological and } \\
\text { Instruments }\end{array}$ & $\begin{array}{l}\text { of anaemia in boys and } \\
\text { Primary results }\end{array}$ \\
\hline $\begin{array}{l}\text { Moschonis } \\
\text { et al. }{ }^{22}\end{array}$ & $\begin{array}{l}\text { Cross- } \\
\text { sectional }\end{array}$ & 2043 & $\begin{array}{l}\text { F: } 1025 \\
\text { M: } 1018\end{array}$ & $\begin{array}{l}\text { Greek children } \\
\text { and adolescents } \\
\text { aged } 9 \text { to } 13 \text { years. }\end{array}$ & $\begin{array}{l}\text { Normal weight } \\
59.0 \% \\
\text { Overweight } 29.7 \% \\
\text { Obese } 11.3 \%\end{array}$ & $\begin{array}{l}\text { 1. Dietary assessment } \\
\text { using the } 24-\mathrm{h} \text { recall } \\
\text { technique } \\
\text { 2. Physical activity } \\
\text { 3. Anthropometry and } \\
\text { physical examination } \\
\text { 4. Biochemical indices } \\
\text { 5. Socio-economic and } \\
\text { perinatal information } \\
\text { 6. Principal component } \\
\text { analysis (PCA) } \\
\text { 7. Breakfast and meal } \\
\text { frequency patterns }\end{array}$ & $\begin{array}{l}\text { Eating behaviour with } \\
\text { more than } 5 \text { meals and } \\
45 \text { minutes of moderate } \\
\text { to vigorous physical } \\
\text { activity is related with } \\
\text { areductionindyslipidaemia } \\
\text { in schoolchildren aged } \\
\text { 9-13 years. }\end{array}$ \\
\hline $\begin{array}{l}\text { Moschonis } \\
\text { et al. }{ }^{18}\end{array}$ & $\begin{array}{l}\text { Cross- } \\
\text { sectional }\end{array}$ & 2073 & $\begin{array}{l}\text { F: } 1041 \\
\text { M: } 1032\end{array}$ & $\begin{array}{l}\text { Primary schools } \\
\text { from four regions } \\
\text { in Greece in } \\
\text { schoolchildren } \\
\text { aged 9-13 years. }\end{array}$ & $\begin{array}{l}\text { Underweight } 2.9 \% \\
\text { Normal weight } \\
56.0 \% \\
\text { Overweight } 29.9 \% \\
\text { Obese } 11.2 \%\end{array}$ & $\begin{array}{l}\text { 1. Dietary assessment } \\
\text { using the } 24 \text {-h recall } \\
\text { technique } \\
\text { 2. Breakfast and meal } \\
\text { frequency patterns } \\
\text { 3. Physical activity } \\
\text { 4. Morphological and } \\
\text { anthropometric } \\
\text { evaluation } \\
\text { 5. Socio-economic and } \\
\text { perinatal information }\end{array}$ & $\begin{array}{l}\text { Increased consumption } \\
\text { of dairy products and } \\
\text { high-fibre food, having } \\
\text { a proper breakfast and } \\
\text { spending more time on } \\
\text { moderate to vigorous } \\
\text { physical activity are } \\
\text { factors which diminish } \\
\text { the probability of obesity } \\
\text { and/or increased levels } \\
\text { of fat mass. }\end{array}$ \\
\hline $\begin{array}{l}\text { Sabiston } \\
\text { and } \\
\text { Crocker }^{24}\end{array}$ & $\begin{array}{c}\text { Cross- } \\
\text { sectional }\end{array}$ & 532 & $\begin{array}{c}\text { F: } 326 \\
\text { M: } 206\end{array}$ & $\begin{array}{l}\text { Caucasian, Asian, } \\
\text { South Asian, } \\
\text { South East Asian, } \\
\text { Hispanic, Aboriginal, } \\
\text { West Asian/Middle } \\
\text { East and Black } \\
\text { Adolescents aged } \\
15 \text { to } 18 \text { years in } \\
\text { Vancouver, British } \\
\text { Columbia, Canada }\end{array}$ & $\begin{array}{l}\text { Underweight } \\
15.4 \% \\
\text { Healthy weight } \\
72.4 \% \\
\text { Overweight } \\
9.8 \% \\
\text { Obese } \\
2.4 \%\end{array}$ & $\begin{array}{l}\text { 1. Perceived } \\
\text { Competence Scales } \\
\text { for Participating } \\
\text { in Regular } \\
\text { Physical Activity } \\
\text { (PCSPA) } \\
\text { 2. Healthy Eating } \\
\text { (PCSHE) } \\
\text { 3. Self- and Task- } \\
\text { Perception Questionnaire } \\
\text { 4. Leisure-Time Exercise } \\
\text { Questionnaire } \\
\text { 5. Adolescent Food Habits } \\
\text { Checklist }\end{array}$ & $\begin{array}{l}\text { Adolescents presenting } \\
\text { obesity expressed the } \\
\text { intention of consuming } \\
\text { healthier foods. Males } \\
\text { are more active while } \\
\text { females seek to eat a } \\
\text { healthier diet. }\end{array}$ \\
\hline $\begin{array}{l}\text { Saucedo- } \\
\text { Molina et } \\
\text { al. } .^{28}\end{array}$ & $\begin{array}{c}\text { Cross- } \\
\text { sectional }\end{array}$ & 1028 & $\begin{array}{l}\mathrm{F}: 605 \\
\mathrm{M}: 423\end{array}$ & $\begin{array}{l}\text { Mexican } \\
\text { adolescents } \\
\text { (15-19 years) }\end{array}$ & $\begin{array}{l}\text { Underweight } \\
\text { F: } 1.3 \% \mathrm{M}: 2.6 \% \\
\text { Low weight } \\
\text { F: } 2.5 \% \mathrm{M}: 6.9 \% \\
\text { Normal weight }\end{array}$ & $\begin{array}{l}\text { 1. International Physical } \\
\text { Activity Questionnaire } \\
\text { (IPAQ) } \\
\text { 2. Risk Factors Associated } \\
\text { with Eating Disorders }\end{array}$ & $\begin{array}{l}\text { The lowest BMI was } \\
\text { related with greater } \\
\text { frequency of meals } \\
\text { and more physical } \\
\text { activity. Subjects with }\end{array}$ \\
\hline
\end{tabular}




\begin{tabular}{|c|c|c|c|c|c|c|c|}
\hline Author & Design & Total $n$ & Sex & Population & $\begin{array}{l}\mathrm{F}: 66.3 \% \mathrm{M}: 61.2 \% \\
\text { Percentage of } \\
\text { subjects by BMI }\end{array}$ & $\begin{array}{l}\text { in children at puberty } \\
\text { Instruments }\end{array}$ & $\begin{array}{l}\text { low weight or } \\
\text { Primary results }\end{array}$ \\
\hline $\begin{array}{l}\text { San } \\
\text { Mauro } \\
\text { et al. } .^{35}\end{array}$ & $\begin{array}{l}\text { Cross- } \\
\text { sectional }\end{array}$ & 189 & $\begin{array}{l}\text { F: } 95 \\
\text { M: } 94\end{array}$ & $\begin{array}{l}\text { School children } \\
\text { between } 6 \text { and } \\
16 \text { years old, } \\
\text { from an elementary } \\
\text { school and a high } \\
\text { school in the } \\
\text { Community of } \\
\text { Madrid, Spain }\end{array}$ & $\begin{array}{l}\text { Overweight } \\
27.6 \% \\
\text { F: } 12.4 \% \mathrm{M}: 15.3 \%\end{array}$ & $\begin{array}{l}\text { 1. International } \\
\text { Physical Activity } \\
\text { Questionnaire } \\
\text { (IPAQ) } \\
\text { 2. Clinical performance } \\
\text { guide to sleep } \\
\text { disorders } \\
\text { 3. Mediterranean } \\
\text { Diet Quality } \\
\text { Index for children } \\
\text { and adolescents } \\
\text { (KIDMED) }\end{array}$ & $\begin{array}{l}\text { Obese boys spent more } \\
\text { time in sedentary leisure } \\
\text { activities }\end{array}$ \\
\hline $\begin{array}{l}\text { Stevens } \\
\text { et al. }{ }^{36}\end{array}$ & $\begin{array}{l}\text { Randomized } \\
\text { Clinical Trial }\end{array}$ & 1455 & $\begin{array}{c}F: 692 \\
M: 755\end{array}$ & $\begin{array}{l}\text { American Indian } \\
\text { Children, 3rd, 4th } \\
\text { and 5th series }\end{array}$ & $\mathrm{NI}$ & $\begin{array}{l}\text { 1. KAB questionnaire. } \\
\text { 2. Food Self-Efficacy } \\
\text { 3. Food Choice Intentions } \\
\text { 4. Which food has more } \\
\text { fat? } \\
\text { 5. Physical Activity } \\
\text { Self-Efficacy } \\
\text { 6. Physical activity } \\
\text { 7. Curriculum knowledge } \\
\text { 8. Attempted weight loss } \\
\text { 9. Healthy body size } \\
\text { perception }\end{array}$ & $\begin{array}{l}\text { Attempts to use diet } \\
\text { and weight-loss } \\
\text { programmes were } \\
\text { negative in the control } \\
\text { group and the } \\
\text { intervention group at } \\
\text { the start of the study. } \\
\text { They increased as the } \\
\text { assessments progressed, } \\
\text { however these changes } \\
\text { were not significant, } \\
\text { indicating that the } \\
\text { intervention had nopositive } \\
\text { effect. The intervention } \\
\text { was based on physical } \\
\text { activity, andtheintervention } \\
\text { group was found to be } \\
\text { more active in all the } \\
\text { assessments, but this } \\
\text { level of activity tended } \\
\text { to diminish with time. }\end{array}$ \\
\hline $\begin{array}{l}\text { Story } \\
\text { et al. }{ }^{16}\end{array}$ & $\begin{array}{l}\text { Cross- } \\
\text { sectional }\end{array}$ & 1441 & $\begin{array}{c}\text { F: } 693 \\
\text { M: } 748 \mathrm{~s}\end{array}$ & $\begin{array}{l}\text { American Indian } \\
\text { Children, average } \\
\text { age } 8.6 \text { years }\end{array}$ & $\begin{array}{l}2.3 \% \text { lean, } 55.5 \% \\
\text { normal weight, } \\
17.9 \% \text { overweight, } \\
24.3 \% \text { obese }\end{array}$ & $\begin{array}{l}\text { 1. KAB questionnaire } \\
\text { 2. Food Choice } \\
\text { Intentions } \\
\text { 3. Food Self-Efficacy } \\
\text { 4. Physical Activity } \\
\text { Self-Efficacy } \\
\text { 5. Attempted Weight } \\
\text { Loss } \\
\text { 6. Health Body Size } \\
\text { Perception }\end{array}$ & $\begin{array}{l}\text { The results of this study } \\
\text { show that the children } \\
\text { were very concerned } \\
\text { about their weight and } \\
\text { that efforts to alter their } \\
\text { weight were common } \\
\text { among overweight } \\
\text { children. }\end{array}$ \\
\hline $\begin{array}{l}\text { Suñé } \\
\text { et al. } .^{29}\end{array}$ & $\begin{array}{c}\text { Cross- } \\
\text { sectional }\end{array}$ & 719 & $\begin{array}{l}F: 361 \\
\text { M: } 358\end{array}$ & $\begin{array}{l}\text { School children } \\
\text { aged } 11-13 \text { years } \\
\text { in Capão da } \\
\text { Canoa, Rio Grande } \\
\text { do Sul State, Brazil }\end{array}$ & $\begin{array}{l}\text { Normal weight } \\
75.2 \% \\
\text { Overweight } \\
21.3 \% \\
\text { Obesity } \\
3.5 \%\end{array}$ & $\begin{array}{l}\text { 1. Nutrition status of } \\
\text { parents } \\
\text { 2. Sedentary behaviour } \\
\text { time } \\
\text { 3. Physical activity } \\
\text { 4. Foods with high } \\
\text { energy density }\end{array}$ & $\begin{array}{l}\text { Carrying out } \\
\text { sedentary activities } \\
\text { for long periods and } \\
\text { consuming foods } \\
\text { with a high energy } \\
\text { a high energy content } \\
\text { are determiners for } \\
\text { increased bodyweight }\end{array}$ \\
\hline $\begin{array}{l}\text { Utter } \\
\text { et al. }{ }^{26}\end{array}$ & $\begin{array}{l}\text { Cross- } \\
\text { sectional }\end{array}$ & 4746 & $\begin{array}{l}F: 2263 \\
M: 2483\end{array}$ & $\begin{array}{l}\text { White, Black, } \\
\text { Asian, Hispanic, } \\
\text { Native American, }\end{array}$ & $\mathrm{NI}$ & $\begin{array}{l}\text { 1.YAQ } \\
\text { 2. Leisure Time } \\
\text { Exercise }\end{array}$ & $\begin{array}{l}\text { Boys and girls with } \\
\text { more sedentary } \\
\text { behaviour were also }\end{array}$ \\
\hline
\end{tabular}




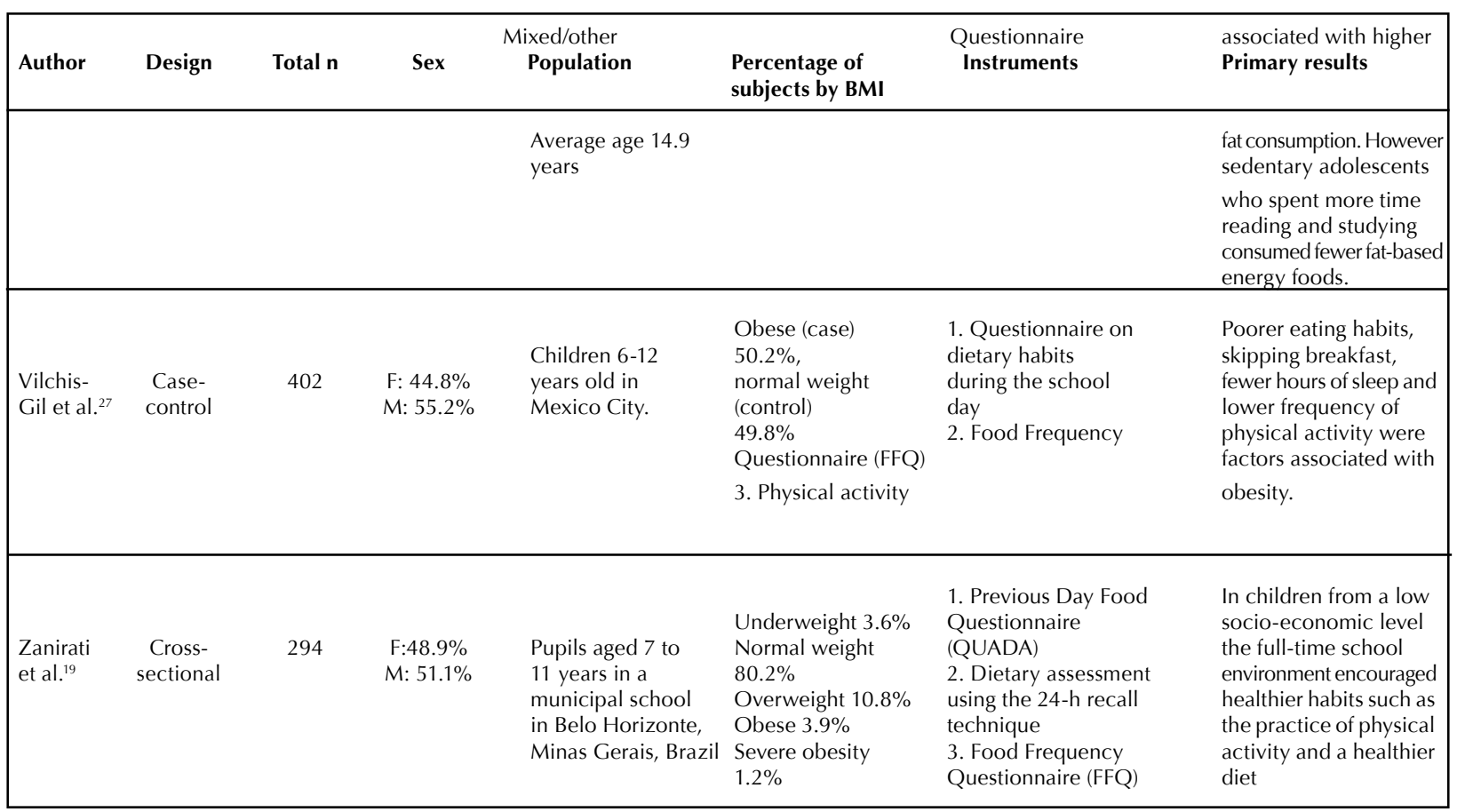

\section{DISCUSSION}

Obesity has a serious effect on adolescents, reducing their quality of life due to the stigma and the social discrimination ${ }^{21}$ triggered by not having an 'acceptable' body. Apart from the psychological effects, obesity is also associated with dyslipidaemia ${ }^{22}$, iron deficiency and iron deficiency with anaemia ${ }^{20}$, as well as cardiovascular disease, diabetes and metabolic syndrome ${ }^{23}$.

Story et al. ${ }^{16}$, observed in their study that overweight subjects had strong intentions of choosing a healthier diet; the same was reported by Sabiston \& Crocker ${ }^{24}$, possibly because normal weight schoolchildren have no need to change their dietary behaviour to achieve changes in their bodies $^{13}$. lannotti \& Wang ${ }^{25}$ say that young whites present many obesogenic behaviours, with excess weight of up to $29.7 \%$. South Africans presented the highest indices of children/adolescents with normal weight (92.1\%); overweight/ obesity was observed to be related with sedentarism and higher age in girls ${ }^{14}$. The highest percentages of overweight were found in Greek schoolchildren, at $30.9 \%{ }^{20}$, and the highest percentage of obesity (24.3\%) in American Indian Children $^{16}$.

Adolescents with normal weight carry out more PA, prefer healthier foods and spend less time in front of screens; these behaviours reflect a healthy lifestyle and are good predictors of quality of life in this population ${ }^{21}$. In their study, Utter, Neumark-Sztainer, Jeffery \& Story ${ }^{26}$ observed that boys and girls with healthier dietary behaviour spent less time in front of the television, or reported inactivity associated with other habits, such as reading. Children and adolescents who sleep less, spend more time in front of the screen or playing video games, and consume more highsugar soft drinks present a higher probability of developing obesity ${ }^{27}$, as well as presenting alterations in their lipid profile and a higher prevalence of dyslipidaemia ${ }^{22}$. It is remarkable that older adolescents tend to carry out less $\mathrm{PA}^{14,25}$ and more sedentary activities, as well as presenting a higher consumption of sweets and soft drinks and a lower intake of fruit and vegetables ${ }^{25}$. Obesogenic behaviour increases with age, and this increase is consistent with the increase in obesity in the population up to adulthood ${ }^{14,25}$. Overweight and obese children live in more obesogenic and sedentary environments, closer to fast-food outlets and other sources of very dense, high-energy foods, and where outdoor physical activity is not encouraged due to the availability of indoor entertainment and vehicle travel ${ }^{14}$. Eating a proper breakfast and/or not skipping breakfast, together with higher consumption of dairy products, were related with a healthier diet and lower $\mathrm{BMl}$; consumption of fibre-rich foods (fruit, vegetables and whole-grain products) was related with lower thickness of cutaneous folds ${ }^{13,18}$; this was corroborated by Vilchis-Gil et al. ${ }^{27}$, who found that higher intake of fruit is associated with lower BMI. Furthermore, higher consumption of carbohydrates (traditional foods with added fat), soft drinks and natural fruit juice were associated with a risk of greater obesity ${ }^{27}$. Children are strongly attracted by high-sugar soft drinks due to a combination of factors, including the flavour and the image of an effervescent drink. Consumption of these drinks is very worrying, since in most houses they are readily 
available and there are no rules on their consumption ${ }^{13}$, constituting an 'invitation' to unhealthy habits in the home. In a study of children and adolescents in the Metropolitan Region of Chile, Liberona et al. ${ }^{17}$ observed that more than half of the schoolchildren were sedentary $(65.4 \%)$ and only $0.7 \%$ had good levels of PA. In a comparison of PA between the sexes, Kruger et al..$^{14}$ observed that boys practice more PA than girls, and this finding was corroborated by Sabiston \& Croker $^{24}$ and Saucedo-Molina et al. ${ }^{28}$ Iannotti and Wang ${ }^{25}$ also found that boys engage in more PA, but say that they also spend more time in sedentary activities, while girls consume more fruit and vegetables, but also more sweets; there was no uniform pattern of greater obesogenic behaviours in one sex or the other, corroborating earlier studies $^{24}$. Female sex and post-menarche development were identified as determining factors for higher body fat content in adolescents ${ }^{14}$, although other authors found that the male sex was more affected by overweight ${ }^{17,18,22,28,29}$. Kruger et al. ${ }^{14}$ reported that the obesity and overweight indices were lower in children aged 11 years and significantly higher in children aged 10 years and adolescents aged 15 years. The percentage of overweight and obese children has been increasing in recent years; it is therefore important to create healthy lifestyle habits from childhood. The family environment is responsible for encouraging healthy dietary habits, but furthermore the parents play a fundamental role in instilling in their children the habit of practising sports, by being more active themselves, setting an example and carrying out PA with their children ${ }^{30}$.

Higher levels of overweight/obesity may be found in smaller households, since families with fewer than 5 members have a higher incomes and more food available per person ${ }^{14}$. Socio-economic level, related with the occupations and incomes of the parents, influences the food intake and PA patterns in the home ${ }^{14}$. Liberona et al..$^{17}$ and Muros et al. ${ }^{21}$ report that adolescents from a lower socio-economic level have less access to healthier foods, such as fruit, vegetables, fish and olive oil. Lower-income families consume a smaller proportion of foods rich in protein and fat, which are more expensive, and instead consume more carbohydrate-rich foods ${ }^{17}$. Suñé et al. ${ }^{29}$ analysed the prevalence of obesity and overweight in schoolchildren aged 11 to 13 years in southern Brazil. They observed that children in private schools had higher levels of obesity and overweight than children in state schools. Furthermore, children in private schools presented a 53\% higher risk of becoming overweight or obese $^{29}$. In Brazil, primary and secondary school children matriculated in state schools tend to come from families with lower incomes than children in private schools, so it is surprising that adolescents from families with better resources and therefore greater access to food of better nutritional quality should present higher rates of overweight and obesity than children with fewer economic resources. Kruger et al. ${ }^{14}$ found similar results, observing that higherincome homes present a higher index of overweight/obese children due to their access to fast foods with a higher fat content. Liberona et al. ${ }^{17}$ observed that obesity was more prevalent in pupils from a lower socio-economic level, while overweight was more prevalent in the mediumhigh socio-economic group and normal weight was most prevalent in pupils from a high socio-economic level. These results suggest that socio-economic level alone is not the determining factor for better (healthier) nutrition, but that the nutritional behaviours and sports habits established by the parents in each home are much more important. Kruger et al. ${ }^{14}$ say that the fact of living in an urban area may be an obesogenic factor, since in such environments there are more sales outlets for fast food and street sellers offering children foods with higher contents of refined carbohydrates and fats. Furthermore, the fear of violence in large metropolitan areas reduces recreational activities in public spaces, and people are more inclined to use their cars even for short journeys.

The regular practice of physical activity, adherence to healthy nutritional habits and proper body composition are agreed to be related with the promotion and/or maintenance of the quality of life in children, adolescents and adults ${ }^{21}$. Diet does not appear to be the principal cause of weight gain, while low levels of PA do appear to be the most important determinant of obesity ${ }^{14,21}$. Moschonis et al. ${ }^{18}$ say that the practice of moderate physical activity for 45 minutes per day is able to diminish significantly the blood concentration of fats in children and adolescents. VilchisGil et al. ${ }^{27}$ state that carrying out at least $1 \mathrm{~h} /$ week of PA in school is sufficient to reduce the probability of becoming obese. Sedentary adolescents have a four times higher risk of presenting overweight or obesity ${ }^{28}$. Some studies say that combining continuous practice of physical activity with proper eating behaviour minimises the prevalence of overweight and/or obesity, and increases the likelihood of behaviour patterns established in children being maintained when they become adults ${ }^{27,31}$.

Policies to encourage healthy eating habits in school are considered to be a high priority as a means of prevention and intervention in pursuit of better health ${ }^{32,33}$. We need to identify the social and environmental conditions which influence the obesogenic behaviours of young people and the need for intervention in children and adolescents ${ }^{25}$. Prevention programmes should be aimed at increasing PA in children in order to improve their current and future weight status ${ }^{14}$.

\section{CONCLUSIONS}

In most of the studies analyzed, schoolchildren presented normal weight, with a tendency for their BMI to increase over time. Overweight and obesity are related with incorrect dietary habits (skipping breakfast, consumption of foods with high fat contents and high-sugar drinks), low levels of PA and long hours devoted to sedentary activities (playing video games or watching TV). Girls pay greater attention to eating a healthy diet, while boys present better levels of PA, however there is no sex-related pattern of healthy 
behaviour. Children and adolescents are exposed to social conditions which tend not to support healthy behaviour; these environments favour the development of poor eating and sports habits.

\section{REFERENCES}

1. World Health Organization. Obesity: preventing and managing the global epidemic. Report of a WHO consultation. Vol. 894, Technical report series. 2000. p. i-xii, 1-253.

2. Rivera JA, de Cossío TG, Pedraza LS, Aburto TC, Sánchez TG, Martorell R. Childhood and adolescent overweight and obesity in Latin America: a systematic review. Lancet Diabetes Endocrinol 2014; 2(4): 321-332.

3. Rokholm B, Baker IL, Sørensen TIA. The levelling off of the obesity epidemic since the year 1999 - a review of evidence and perspectives. Obes Rev 2010; 11(12): 835-846.

4. Onis M. Preventing childhood overweight and obesity. J Pediatr 2015; 91(2): 105-107.5. Friedman MA, Wilfey DE, Pike KM, Striegel-Moore RH, Rodinf J. The Relationship Between Weight and Psychological Functioning Among Adolescent Girls. Obes Res 1995; 3(1): 57-62.

6. Neumark-Sztainer D, Story M, French SA, Hannan PJ, Resnick MD, Blum RW. Psychosocial concerns and health-compromising behaviors among overweight and nonoverweight adolescents. Obes Res 1997; 5(3): 237-249.7. Crago M, Shisslak CM, Estes LS. Eating disturbances among American minority groups: A review. Int J Eat Disord 1996; 19(3): 239-248.

8. Toral N, Slater B. Transtheoretical model approach in eating behavior. Cien Saude Colet 2007; 12(6): 1641-1650.

9. Martins CR, Pelegrini A, Matheus SC, Petroski EL. Dissatisfaction with body image and relation with nutritional status, body adiposity and symptoms of anorexia and bulimia in adolescents. Rev Psiquiatr do Rio Gd do Sul 2010; 32(1): 19-23.

10. Vale AMO, Kerr LRS, Bosi MLM. Risk behaviors for eating disorders among female adolescents from different social strata in the Brazilian Northeastern. Cien Saude Colet 2011; 16(1): 121-132.

11. Castro IRR de, Levy RB, Cardoso $L$ de $O$, Passos MD dos, Sardinha $L M V$, Tavares $L F$, et al. Body image, nutritional status and practices for weight control among Brazilian adolescents. Cien Saude Colet 2010; 15(suppl 2): 3099-3108.

12. Flament MF, Hill EM, Buchholz A, Henderson K, Tasca GA, Goldfield G. Internalization of the thin and muscular body ideal and disordered eating in adolescence: The mediation effects of body esteem. Body Image 2012; 9(1): 68-75.

13. Te Velde SI, Singh A, Chinapaw M, De Bourdeaudhuij I, Jan N, Kovacs E, et al. Energy balance related behaviour: personal, home- and friend-related factors among schoolchildren in Europe studied in the ENERGY-project. PLOS One 2014; 9(11): e111775.

14. Kruger $R$, Kruger $H$, Macintyre $U$. The determinants of overweight and obesity among 10-to 15-year-old schoolchildren in the North West Province, South Africa - the THUSA BANA (Transition and Health during Urbanisation of South Africans; BANA, children) study. Public Health Nutr 2005; 9(3): 351-358.

15. Parsons T, Power C, Logan S, Summerbell C. Childhood predictors of adult obesity: a systematic review. Int J Obes 1999; 23(Supp/ 8): S1-107.

16. Story M, Stevens J, Evans M, Cornell CE, Juhaeri, Gittelsohn J, et al. Weight Loss Attempts and Attitudes toward Body Size, Eating, and Physical Activity in American Indian Children:
Relationship to Weight Status and Gender. Obes Res 2001; 9(6): 356-363.

17. Liberona Y, Castillo O, Engler V, Villarroel L, Rozowski J. Nutritional profile of schoolchildren from different socioeconomic levels in Santiago, Chile. Public Health Nutr 2010; 14(1): 142-149.

18. Moschonis G, Kalliora AC, Costarelli V, Papandreou C, Koutoukidis D, Lionis $C$, et al. Identification of lifestyle patterns associated with obesity and fat mass in children: the Healthy Growth Study. Public Health Nutr 2014; 17(3): 614-624.

19. Zanirati VF, Lopes ACS, Santos LC dos. Contribution of the extended school shift to the food and physical activity profile among schoolchildren. Rev Panam Salud Publica 2014; 35(1): 38-45.

20. Manios Y, Moschonis G, Chrousos GP, Lionis C, Mougios V, Kantilafti $M$, et al. The double burden of obesity and iron deficiency on children and adolescents in Greece: The Healthy Growth Study. J Hum Nutr Diet 2013; 26(5): 470-478.

21. Muros JJ, Pérez FS, Ortega FZ, Gámez Sánchez VM, Knox $E$. The association between healthy lifestyle behaviors and health-related quality of life among adolescents. J Pediatr 2017; 93(4): 406-412.

22. Moschonis G, Mavrogianni C, Karatzi K, latridi V, Chrousos $G P$, Lionis $C$, et al. Increased physical activity combined with more eating occasions is beneficial against dyslipidemias in children. The Healthy Growth Study. Eur J Nutr 2013; 52(3): 1135-1144.

23. Wang G, Dietz WH. Economic burden of obesity in youths aged 6 to 17 years: 1979-1999. Pediatrics 2002; 109(5): E811.24. Sabiston CM, Crocker PRE. Examining an Integrative Model of Physical Activity and Healthy Eating Self-Perceptions and Behaviors Among Adolescents. J Adolesc Health 2008; 42(1): 64-72.25. lannotti RJ, Wang J. Trends in physical activity, sedentary behavior, diet, and BMI among US adolescents, 2001-2009. Pediatrics 2017; 132(4): 606-614.

26. Utter J, Neumark-Sztainer D, Jeffery R, Story M. Couch potatoes or french fries: are sedentary behaviors associated with body mass index, physical activity, and dietary behaviors among adolescents? J Am Diet Assoc 2003; 103(10): 1298-1305.

27. Vilchis-Gil J, Galván-Portillo M, Klünder-Klünder M, Cruz $M$, Flores-Huerta S. Food habits, physical activities and sedentary lifestyles of eutrophic and obese school children: a case-control study. BMC Public Health 2015; 15(1): 124.

28. Saucedo-Molina $T$ de J, Jiménez JR, Macías LAO, Castillo MV, Hernández RCL, Cortés TLF. Relationship between body mass index, physical activity and meal times in Mexican adolescents. Nutr Hosp 2015; 32(3): 1082-1090.

29. Suñé FR, Dias-da-Costa JS, Olinto MTA, Pattussi MP. Prevalence of overweight and obetisty and associated factors among scoolchildren in a southern Brazilian city. Cad Saúde Pública 2007; 23(6): 1361-1371.

30. Farajian P, Risvas G, Karasouli K, Pounis GD, Kastorini $C M$, Panagiotakos DB, et al. Very high childhood obesity prevalence and low adherence rates to the Mediterranean diet in Greek children: The GRECO study. Atherosclerosis 2011; 217(2): 525-530.

31. Biddle S, Asare M. Physical Activity and Mental Health in Children and Adolescents: A Review of Reviews. Br J Sports Med 2011; 45(11): 886-895.

32. Lazzoli JK, Nóbrega ACL da, Carvalho T de, Oliveira MAB de, Teixeira JAC, Leitão MB, et al. Physical activity and health in childhood and adolescence. Rev Bras Med do Esporte 
1998; 4(4): 107-109.

33. Kastorini CM, Lykou A, Yannakoulia M, Petralias A, Riza E, Linos $A$, et al. The influence of a school-based intervention programme regarding adherence to a healthy diet in children and adolescents from disadvantaged areas in Greece: the DIATROFI study. J Epidemiol Community Health 2016; 70(7): 671-677.

34. Sharif Ishak SIZ, Chin YS, Mohd Taib MN, Mohd Shariff Z. School-based intervention to prevent overweight and disordered eating in secondary school Malaysian adolescents:
A study protocol. BMC Public Health 2016; 16(1): 1101.

35. San Mauro I, Megías A, García de Angulo B, Bodega P, Rodríguez $P$, Grande $G$, et al. Influencia de hábitos saludables en el estado ponderal de niños y adolescentes en edad escolar. Nutr Hosp 2015; 31(5): 1996-2005.

36. Stevens J, Story M, Ring K, Murray D, Cornell CE, Juhaeri, et al. The impact of the Pathways intervention on psychosocial variables related to diet and physical activity in American Indian schoolchildren. Prev Med (Baltim) 2003; 37(6 Pt 2): S70-S79. 